\title{
Influence of orbital forcing and sea level changes on sedimentation patterns in the Timor Sea during the last $260 \mathrm{ka}$
}

\author{
Eva Moreno, ${ }^{1}$ Franck Bassinot, ${ }^{2}$ François Baudin, ${ }^{3}$ and Marie-Thérèse Vénec-Peyré ${ }^{1}$ \\ Received 24 January 2007; revised 15 June 2007; accepted 26 September 2007; published 31 January 2008.
}

[1] A multiproxy study of core MD98-2166 makes it possible to investigate the influence of orbital forcing and sea level changes on Timor Sea sedimentation during the last $260 \mathrm{ka}$. Spectral analysis reveals a strong imprint of obliquity in all proxies. This is particularly puzzling for the $\mathrm{CaCO}_{3}$ and total organic carbon (TOC) records since recent data obtained on nearby core MD01-2378, collected at a shallower water depth, showed a concentration of spectral power in the eccentricity and precession bands. Our results suggest that while sedimentary record in shallower core MD01-2378 shows a clear low-latitude response, that of core MD98-2166 reflects a stronger influence of high-latitude forcing through deepwater changes. In addition, Rock-Eval analyses show that part of the organic carbon could be of terrestrial origin, especially during glacial periods. This suggests that glacial/interglacial TOC fluctuations not only reflect changes of marine productivity and/or preservation at the seafloor but also reflect enhanced input of terrestrial material during periods of low sea level.

Citation: Moreno, E., F. Bassinot, F. Baudin, and M.-T. Vénec-Peyré (2008), Influence of orbital forcing and sea level changes on sedimentation patterns in the Timor Sea during the last $260 \mathrm{ka}$, Paleoceanography, 23, PA1207, doi:10.1029/2007PA001423.

\section{Introduction}

[2] The hydrographic evolution of the tropical ocean has been given much attention in recent years because increasing evidence suggests that it may play a key role in modulating global climate changes on orbital and suborbital timescales [Cane and Clement, 1999; Wang, 1999; Stott et al., 2002; Visser et al., 2004]. In that respect, the Indonesian Archipelago is a key area for several reasons: (1) It is located within the Western Pacific Warm Pool (WPWP), one of the major source of global latent heat to the atmosphere [Yan et al., 1992]; (2) its climate is affected by two of the world's most dramatic climatic features on seasonal and interannual timescales, the monsoon and $\mathrm{El}$ Niño-Southern Oscillation (ENSO); and (3) it constitutes the main pathway between the Pacific and the Indian oceans for the surface water return flow of the Great Conveyor Belt. The surface and subsurface waters that travel across the Indonesian Archipelago, the so-called Indonesian Throughflow (ITF), represent an important component of the thermohaline circulation loop, which ultimately supplies heat and moisture to the high latitudes [Macdonald, 1998; Ganachaud and Wunsch, 2000].

[3] Owing to the presence of vast areas with low bathymetry in the Indonesian Archipelago, it is likely that past changes in sea level had important climatic and hydrographic

\footnotetext{
${ }^{1}$ UMR 5143, Département d'Histoire de la Terre, Muséum National d'Histoire Naturelle, Paris, France.

${ }^{2}$ Laboratoire des Sciences du Climat et de l'Environnement, Domaine du CNRS, Gif-sur-Yvette, France.

${ }^{3}$ UMR 7072 and Département de Géologie Sédimentaire, Université Pierre et Marie Curie Paris 6, Paris, France.
}

Copyright 2008 by the American Geophysical Union. 0883-8305/08/2007PA001423 implications. During the Last Glacial Maximum (LGM), sea level dropped by about $125 \mathrm{~m}$ [Yokoyama et al., 2000] which doubled the exposed land [De Deckker et al., 2003]. Therefore the region could not claim to be the "maritime continent" as it is today [Ramage, 1968; De Deckker et al., 2003]. While it appears that the connection between the Pacific and Indian Oceans was always maintained through the deepest pathways (ex. Timor, Ombai and Lombok straits), the ITF intensity most probably decreased because of the closing of shallow pathways [Wang, 1999; Gingele et al., 2002; De Deckker et al., 2003]. Furthermore, the drastic reduction in the ocean/continent surface ratio likely resulted in the reduction of the water and heat transfer from the ocean to the atmosphere and affected the climate of the region with potential implications at a global scale.

[4] Despite the climatic and oceanographic importance of the Indonesian Archipelago, there are still few data available for understanding climatic and hydrographic variability associated to orbital forcing and sea level changes in this area. Most of the available studies were based on short cores that only covered one climatic cycle [Müller and Opdyke, 2000; Gingele et al., 2002] or on cores with low sedimentation rates [Wang et al., 1999; van der Kaars et al., 2000; Kershaw et al., 2003]. Only a few recent studies have been performed on long cores covering two to three climatic cycles with a high sedimentation rate [Holbourn et al., 2005; Kawamura et al., 2006]. These studies focused on changes in marine productivity and concluded that surface productivity was higher during glacial periods [Holbourn et al., 2005; Kawamura et al., 2006]. This increased glacial productivity was interpreted by Holbourn et al. [2005] as resulting from an increased boreal winter monsoon driven by changes in the precession-related insolation, and modulated by sea level and ITF circulation. 


\section{Modern}

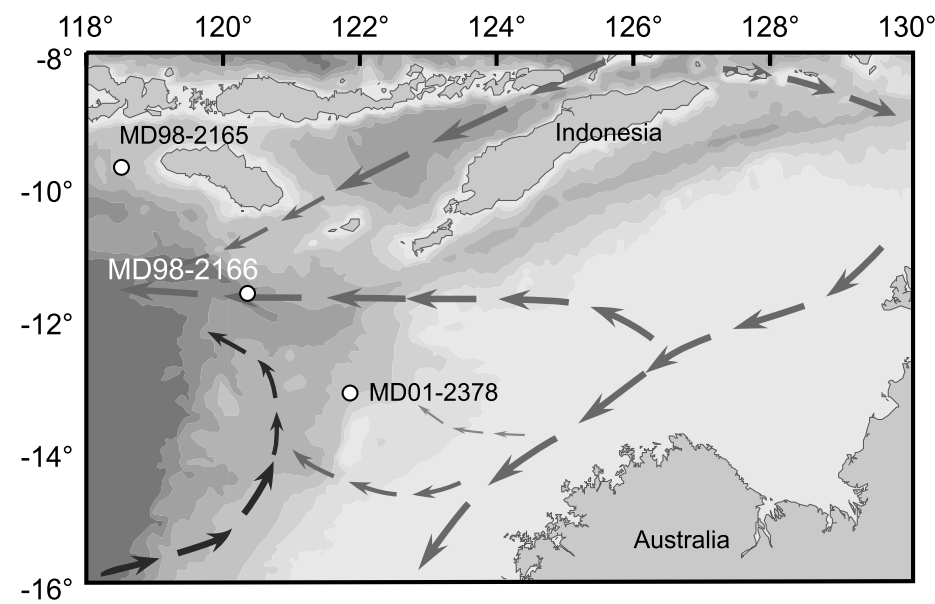

\section{Glacial}

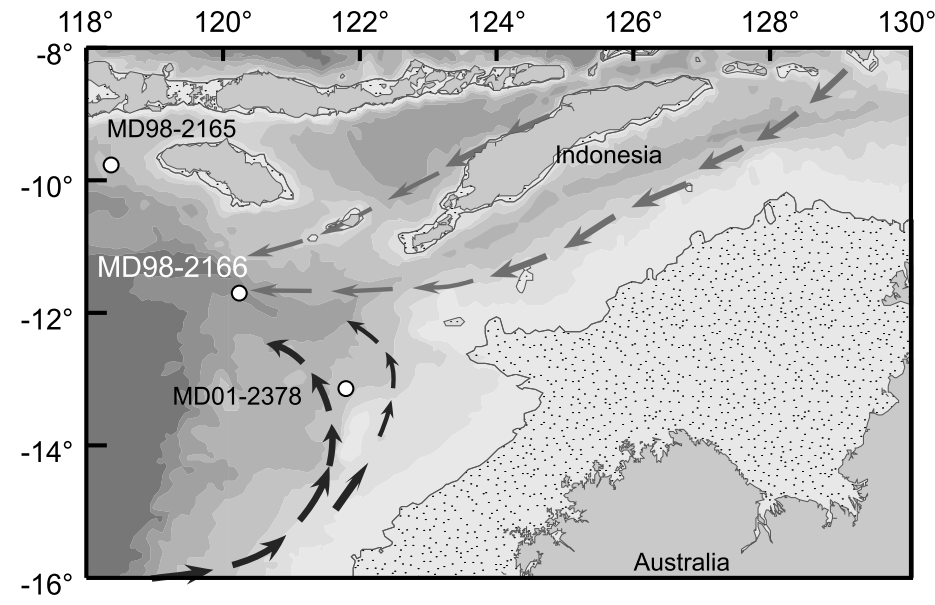

Figure 1. Locality map of core MD98-2166 and other cores used for this study and oceanographic conditions around the Indonesian Archipelago during glacial and modern times [after Holbourn et al., 2005]. The dotted area represents the estimated extent of exposed continental shelf during the Last Glacial Maximum, and the arrows indicate the surface current systems of the Timor passage. Grey arrows correspond to the Indonesian Throughflow outflow, and black arrows correspond to cold currents originating from the south.

[5] Taking advantage of core MD98-2166, retrieved in the Timor Sea (Figure 1), close to core MD01-2378 [Holbourn et al., 2005] but at a greater water depth, we propose (1) to investigate past changes of total organic carbon content (TOC) deposition at orbital timescale and (2) to study the implications of sea level changes and deep-sea circulation on pelagic carbonate sedimentation in the Timor Sea.

\section{Material}

[6] Core MD98-2166 has a length of $34.76 \mathrm{~m}$. It was collected at $11.577 \mathrm{~S}$ and $120.275 \mathrm{E}$, at $3875 \mathrm{~m}$ of water depth in the Timor Sea during the MD111-IMAGES IV cruise of R/V Marion Dufresne.
[7] Smear slide observations showed that the core is very rich in biogenic material (about 45\%) consisting of nannofossils $(20 \%)$, foraminifers $(5 \%)$ and silica organisms $(20 \%)$. The terrigenous material consists mainly of clays $(35 \%)$, silts and sands (10\%), amorphous components and oxyhydroxides (5\%). Pyrite is present all over the core, sometimes in dark patches. Clay abundance seems to increase slightly down core. Sediment composition does not vary significantly between glacial and interglacial periods, except for foraminifer content whose percentage increases during interglacials. Two volcanic ash layers were identified at 27 and $34 \mathrm{~m}$ down core. 
[8] We compared our results from core MD98-2166 to those from core MD98-2165, retrieved north of MD982166 , at $9.6500^{\circ} \mathrm{S}$ and $118.3400^{\circ} \mathrm{E}$ and $2100 \mathrm{~m}$ water depth [Levi, 2003; Waelbroeck et al., 2006] and core MD01-2378, retrieved southeast of MD98-2166, at $13.0825^{\circ} \mathrm{S}-$ $121.7880^{\circ} \mathrm{E}$, and $1783 \mathrm{~m}$ water depth [Holbourn et al., 2005; Kawamura et al., 2006].

\section{Methods}

\subsection{Isotopic Measurements}

[9] The stable $\mathrm{O}$ and $\mathrm{C}$ isotopic composition of surface dwelling planktonic foraminifera Globigerinoides ruber (white) picked from the 250-315 $\mu \mathrm{m}$ size fraction was measured at the Laboratoire des Sciences du Climat et de l'Environnement on a Finnigan $\Delta+$ mass spectrometer. The $\delta^{18} \mathrm{O}$ and $\delta^{13} \mathrm{C}$ were calculated versus VPDB through calibration to the NBS19 calcite standard [Coplen, 1988]. The mean external reproducibility $(1 \sigma)$ of carbonate standards is $\pm 0.05 \%$ or for $\delta^{18} \mathrm{O}$ and $\pm 0.03 \%$ or for $\delta^{13} \mathrm{C}$.

\section{2. $\mathrm{CaCO}_{3}$ and Organic Carbon}

[10] Calcium carbonate contents $\left(\mathrm{CaCO}_{3}\right.$ in weight percent) were measured using a carbonate bomb and total carbon contents were determined using a LECO IR-212 analyzer. Total organic carbon content (TOC in weight percent) is calculated as the difference between total carbon and carbonate carbon, assuming that all carbonate is pure calcite or aragonite. The precision for these analyses is $\pm 0.5 \%$ for calcium carbonate and $\pm 0.1 \%$ for total carbon.

[11] TOC concentration is a bulk sedimentary parameter that represents the fraction of organic matter that survived degradation during sinking to the seafloor and early diagenesis in the sediment. This parameter reflects the quantity of organic matter, but it should be kept in mind that organically bound oxygen, hydrogen, sulphur and nitrogen can contribute up to $50 \%$ of the total sedimentary organic matter. Thus, in immature samples, 1\% TOC usually corresponds to 1.5 to $2.0 \%$ of organic matter.

[12] Information on the quantity, type and thermal maturity of the organic matter was obtained using Rock-Eval pyrolysis performed on finely powdered bulk sediment [Espitalié et al., 1985]. The parameter $\mathrm{S}_{2}$ is the amount of hydrocarbon released during stepwise temperature pyrolysis $\left(300^{\circ}-600^{\circ} \mathrm{C}\right)$, and is expressed in hydrocarbons (HC) per gram of dry sediment. The hydrogen index (HI) is the normalized $\mathrm{S}_{2}$ value $\left(\mathrm{HI}=\mathrm{S}_{2} /\right.$ TOC $\left.\times 100\right)$ expressed in milligram HC per gram of TOC. It is characteristic of the type of organic matter (terrestrial or oceanic [Tissot and Welte, 1984; Espitalié et al., 1985]).

[13] $T_{\max }$ is the temperature at maximum pyrolytic hydrocarbon generation expressed in ${ }^{\circ} \mathrm{C}$. It varies as a function of the natural thermal maturity of the organic matter.

[14] The origin of the organic matter can be evaluated using the relationship between HI versus $T_{\max }$ [Espitalié et al., 1985]. According to these authors, the organic matter can be classified in four types. Type I and type II correspond to fresh organic matter of lacustrine and marine origin, respectively. Type III is derived from terrestrial higher plants or highly oxidized organic matter, whereas type IV corresponds to residual deeply altered organic matter [Peters, 1986].

[15] Sometimes the HI can be underestimated because of mineral matrix effects (e.g., adsorption on clay mineral surfaces of hydrocarbons generated during pyrolysis). Langford and Blanc-Valleron [1990] suggested an alternative approach to assess organic matter type by using the $S_{2}$ versus percent TOC plot.

\subsection{Palynofacies}

[16] Palynofacies analysis (the study of all the particulate organic matter present in the sediment) was performed on selected samples using a Zeiss Axoplan microscope. After drying, bulk sediment samples were digested in $\mathrm{HCl}-\mathrm{HF}$ acids in order to concentrate the organic matter. Neither oxidation nor ultrasonic treatments were carried out during processing as all the particles were of interest in this study and may be selectively destroyed by such procedures. The residue was separated into two fractions. One was directly mounted on glass microscope slides as strew mounts and the other after sieving through a $15 \mu \mathrm{m}$ sieve.

[17] The classification of palynofacies has always been rather subjective [Tyson, 1995]. For this study, a classification was chosen in order to obtain as much paleoenvironmental and paleoclimatic information as possible from palynofacies analysis. The particles distinguished during these preliminary qualitative investigations are the following: (1) Phytoclasts comprise all opaque and translucent land plant debris; different subgroups can be observed within this fraction and they were distinguished during the analysis. (2) Sporomorphs comprise the land-derived pollen grains and spores. (3) Amorphous organic matter (AOM) comprises all particulate organic components that appear structureless at the scale of light microscopy. (4) Marine phytoplankton comprises all dinoflagellate cysts, acritarchs, and other marine algae. (5) Scolecodonts comprise the chitinous pieces of worms.

\subsection{Magnetic Susceptibility}

[18] Magnetic susceptibility (MS) data were acquired on half split sections of core MD98-2166 at $2 \mathrm{~cm}$ intervals using a Bartington MS2 susceptibility system equipped with a MS2E1 surface scanning spot sensor. MS was reported in dimensionless volume units $\left(\times 10^{-5}\right.$ SI units $)$.

[19] MS is the ratio of induced magnetization to an applied magnetic field. Its value is a function of magnetic particle concentrations and mineralogy [Thompson and Oldfield, 1986]. Magnetic susceptibility has low grain size dependence and can be considered as the best parameter for assessing magnetic concentrations [Peters and Dekkers, 2003].

[20] MS is mostly influenced by ferromagnetic minerals such as (titano-) magnetite or greigite $\left(\mathrm{Fe}_{3} \mathrm{~S}_{4}\right)$. Changes in magnetic susceptibility reflect changes in the concentration of magnetic materials, which may result from changes in the terrigenous source supply and/or transport mechanisms. The relationship between $\mathrm{MS}$ and climatic changes is well documented in marine sediments [Bloemendal et al., 1992; Thouveny et al., 2000; Moreno et al., 2002]. In tropical climates, the balance between aridity and precipi- 
a) MD98-2165 $\delta^{18} \mathrm{O}$ (G. ruber) \%

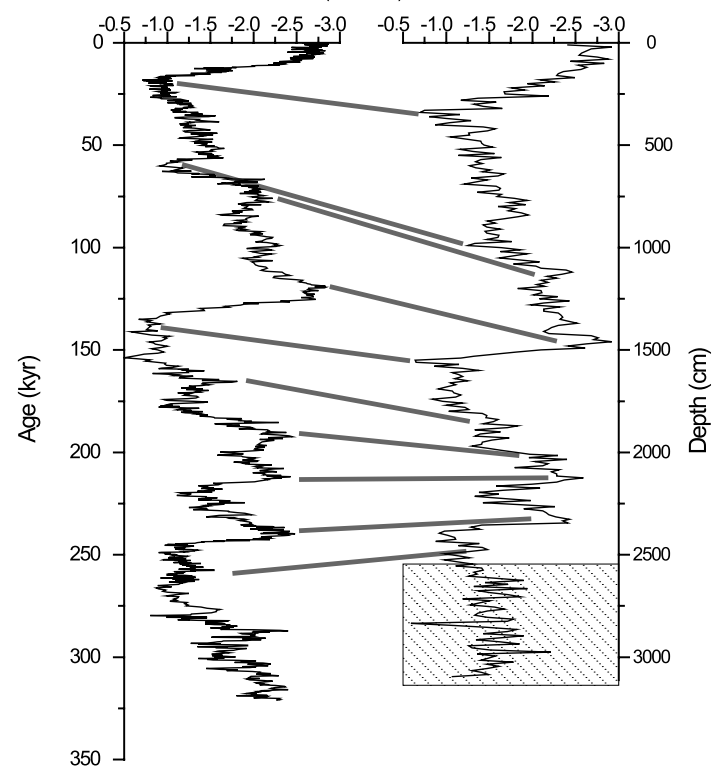

b)

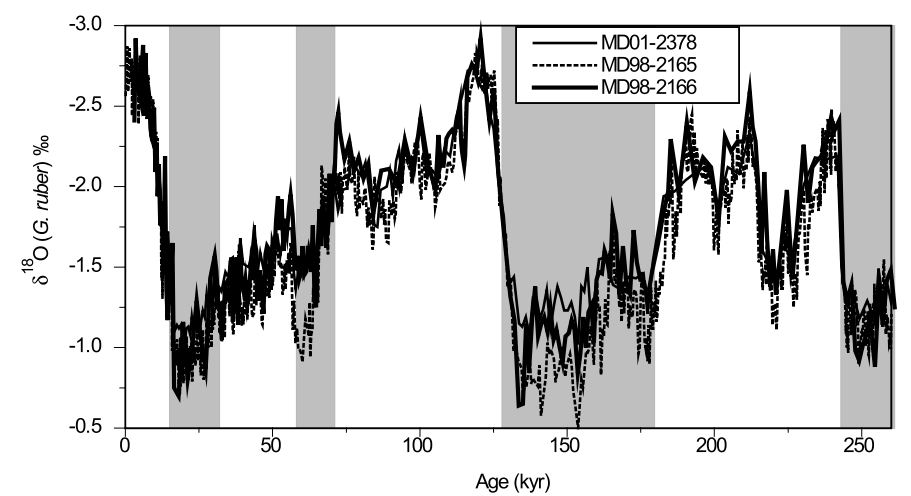

Figure 2. (a) Planktonic oxygen isotopic record versus depth in core MD98-2166. For dating the core was correlated with the planktonic $\delta^{18} \mathrm{O}$ record of the neighbor core MD98-2165 [Levi, 2003; Waelbroeck et al., 2006]. (b) Planktonic oxygen isotopic records of the three cores versus age using the MD98-2165 age model.

tation will determine the main mechanism by which terrigenous material will be brought to the ocean. Periods of high precipitation correspond to periods of higher river transportation, whereas periods of stronger aridity are more favorable to aeolian transport. During periods of lowstand sea levels, the exposure of continental shelves can also favor a greater delivery of continental supply into the ocean.

[21] Beside climatic and sea level changes, sedimentation conditions can additionally exert an important control factor on the MS record. Organic matter input, oxygen concentration of the bottom water and/or sedimentation rate will determine redox boundaries within the sediment and lead to dissolution or precipitation of ferromagnetic minerals resulting in the decrease or increase of MS values [Bloemendal et al., 1992; Roberts and Turner, 1993; Passier et al., 1998; Demory et al., 2005]. These changes are particularly pronounced in (1) turbidites [Robinson, 2001], (2) sapropels of the Mediterranean Sea [Passier et al., 1998; Larrasoana et al., 2003] and (3) at glacial/interglacial transitions [Thomson et al., 1996; Reitz et al., 2004].

\subsection{Spectral Analysis}

[22] To extract the significant periodicities over the 0 $260 \mathrm{ka}$ interval, we performed Blackman-Tuckey and cross Blackman-Tuckey spectral analyses of MD98-2166 and MD01-2378 proxy data sets using the Analyseries software [Paillard et al., 1996]. Prior to analysis, each record was interpolated at a constant time increment of $1 \mathrm{ka}$. Spectral analyses were performed using a Bartlett window with 50\% lag of the autocovariance series. The bandwidth is equal to
0.0115 and the error estimate ( $\Delta$ power) in the power spectrum is such that $0.563664<\Delta$ power/power $<2.72216$ (power being the spectral power at a given frequency band).

\section{Results}

\subsection{Age Model}

[23] The age model of core MD98-2166 was developed by correlating its $\delta^{18} \mathrm{O}$ record to the high-resolution (mean sampling resolution better than 300 years), G. ruber $\delta^{18} \mathrm{O}$ record of nearby core MD98-2165 (Figure 2). The upper $<40$ ka part of core MD98-2165 was dated on the basis of 20 accelerated mass spectrometry (AMS) ${ }^{14} \mathrm{C}$ dates obtained on monospecific G. ruber (white) samples [Levi, 2003; Waelbroeck et al., 2006]. For the time period $>40 \mathrm{ka}$, the chronology of core MD98-2165 was developed by correlation to the ice core record of Dome C [Levi, 2003]. In order to make valid comparisons between the three cores mentioned in this paper, the $>40 \mathrm{ka}$ age model of core MD982165 was also transferred to core MD01-2378 through correlation of the planktonic $\delta^{18} \mathrm{O}$ records. The tying of the isotopic records in cores MD98-2166 and MD98-2165 is straightforward for the two last climatic cycles, down to marine isotopic stage 8.4 at about $27.5 \mathrm{~m}$. Deeper down core, however, isotopic variations in Core MD98-2166 cannot be correlated with confidence to the isotopic stratigraphy of core MD98-2165, which may indicate problems in the sedimentation history of core MD98-2166. Thus, in this paper, we will discuss only the interval 0-260 ka. Between 


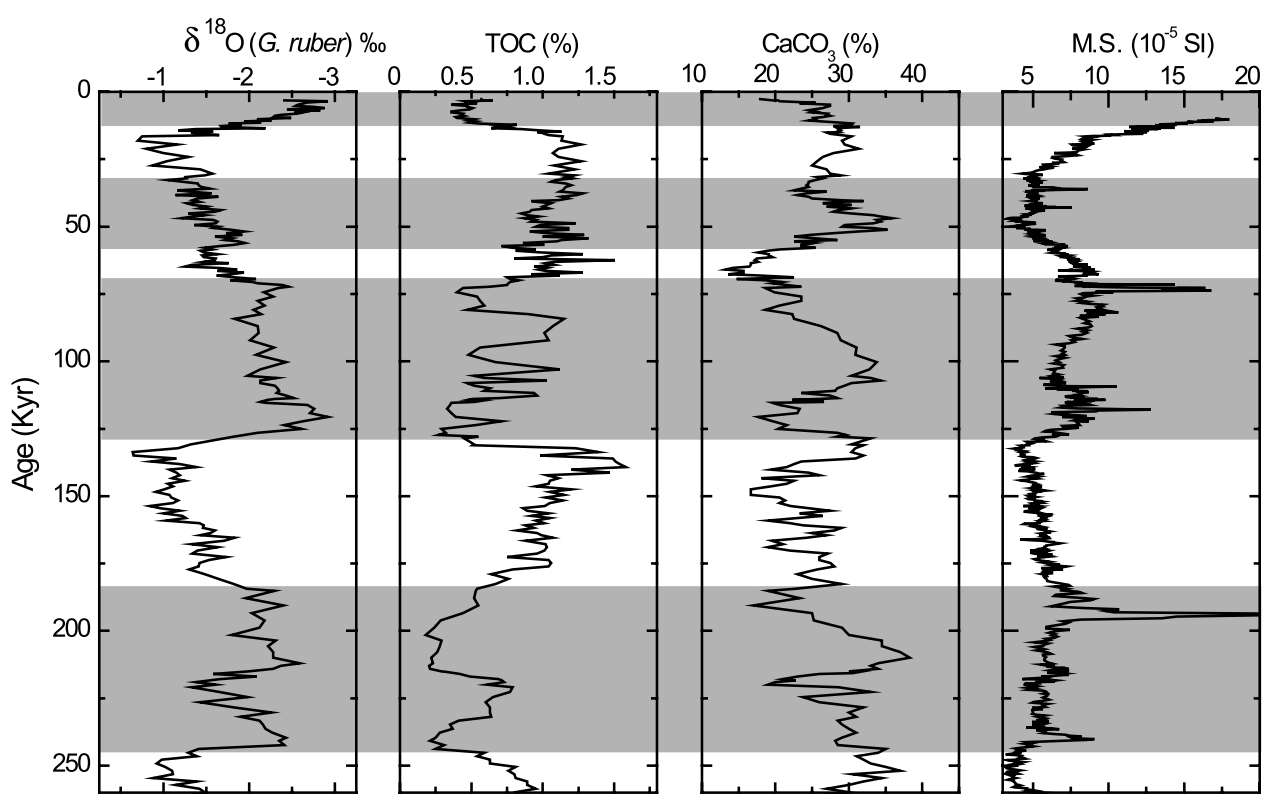

Figure 3. Planktonic $\delta^{18} \mathrm{O}$, total organic carbon (TOC), carbonate, and magnetic susceptibility (MS) records in core MD98-2166 versus age.

tie points, ages were linearly interpolated assuming constant sedimentation rates.

[24] The $10 \mathrm{~cm}$ sampling interval in core MD98-2166 translates into an average time resolution of $1.1 \mathrm{ka}$, varying from 0.3 to $4.6 \mathrm{ka}$ along the core. The overall, up-core increase in average sedimentation rate likely reflects an oversampling artifact during the giant piston coring [Thouveny et al., 2000; Széréméta et al., 2004].

\subsection{Calcium Carbonate and Organic Carbon Fluctuations in Response to Climatic Changes}

[25] Both carbonate and organic carbon records show significant variations during the last 260,000 years (Figure 3). Calcium carbonate fluctuations are important, but do not show a clear glacial-interglacial pattern. Carbonate content ranges between 14.7 and $38.3 \%$ during interglacials and between 13.2 and 37\% during glacials, both periods showing an average value around $26 \%$. In contrast, the organic matter record shows significant difference between glacial and interglacial periods with low TOC (ranging between 0.18 and $1.15 \%$ and averaging $0.5 \%$ ) during interglacials and higher TOC (ranging between 0.51 and $1.58 \%$ and averaging $1 \%$ ) during glacials.

[26] The HI values range between 106 and $277 \mathrm{mg} \mathrm{HC} / \mathrm{g}$ TOC, which is very low for marine sediments. Mean values are slightly higher for interglacial periods but considering the large standard deviation obtained, there is not a clear difference between glacial and interglacial stages. The temperature $\left(T_{\max }\right)$ at maximum pyrolytic hydrocarbon generation ranges between $365^{\circ} \mathrm{C}$ and $430{ }^{\circ} \mathrm{C}$ indicating immature organic matter as expected for recent sediments. As for HI, there is not clear difference between glacial and interglacial periods. Finally $\mathrm{S}_{2}$ which indicates the amount of hydrocarbon released during pyrolysis, ranges between
2.24 and 0.34 , with higher mean values during glacial periods (1.65) than during interglacials (0.93).

[27] Figure 4 shows the plots of HI versus $T_{\max }$ and of $\mathrm{S}_{2}$ versus TOC. The mineral matrix effect has no importance here, as indicated by the fact that the regression line through our samples crosses the $\mathrm{S}_{2}$ axis just above the origin. This may indicate a minor overestimation of the HI values $(\approx 35 \mathrm{mg} \mathrm{HC} / \mathrm{g}$ TOC) because a slight amount of nonhydrocarbon effluents were detected during pyrolysis.

[28] The plots on Figure 4 show that the organic matter lies at the type II/III boundary, which suggests that it is of terrestrial origin or highly oxidized marine organic matter. There are very small changes between glacial and interglacial periods. However, interglacial samples tend toward type II suggesting a higher marine influence.

\subsection{Palynofacies Analysis}

[29] AOM constitutes more than $95 \%$ of the organic particles of all studied samples. Two types of AOM may be distinguished: granular, orange to dark brown translucent AOM, and greyish to dark AOM, very rich in dispersed framboidal pyrite. The latter is dominant during interglacials periods, whereas the first type dominates in glacial periods (Figure 5). The weak fluorescence of the grey AOM indicates intense degradation of the labile organic matter, which is also documented by the high pyritic content.

[30] The very high abundance of AOM in the studied samples makes it difficult to correctly evaluate the origin of the organic matter. The filtered slides reveal variations in the relative abundance of structured organic components Phytoclasts are an important constituent of the palynofacies. Well-preserved, large $(>50 \mu \mathrm{m})$ plant tissue structures are found in glacial samples. They are less abundant, smaller and more oxidized in interglacial samples (Figure 5). This 

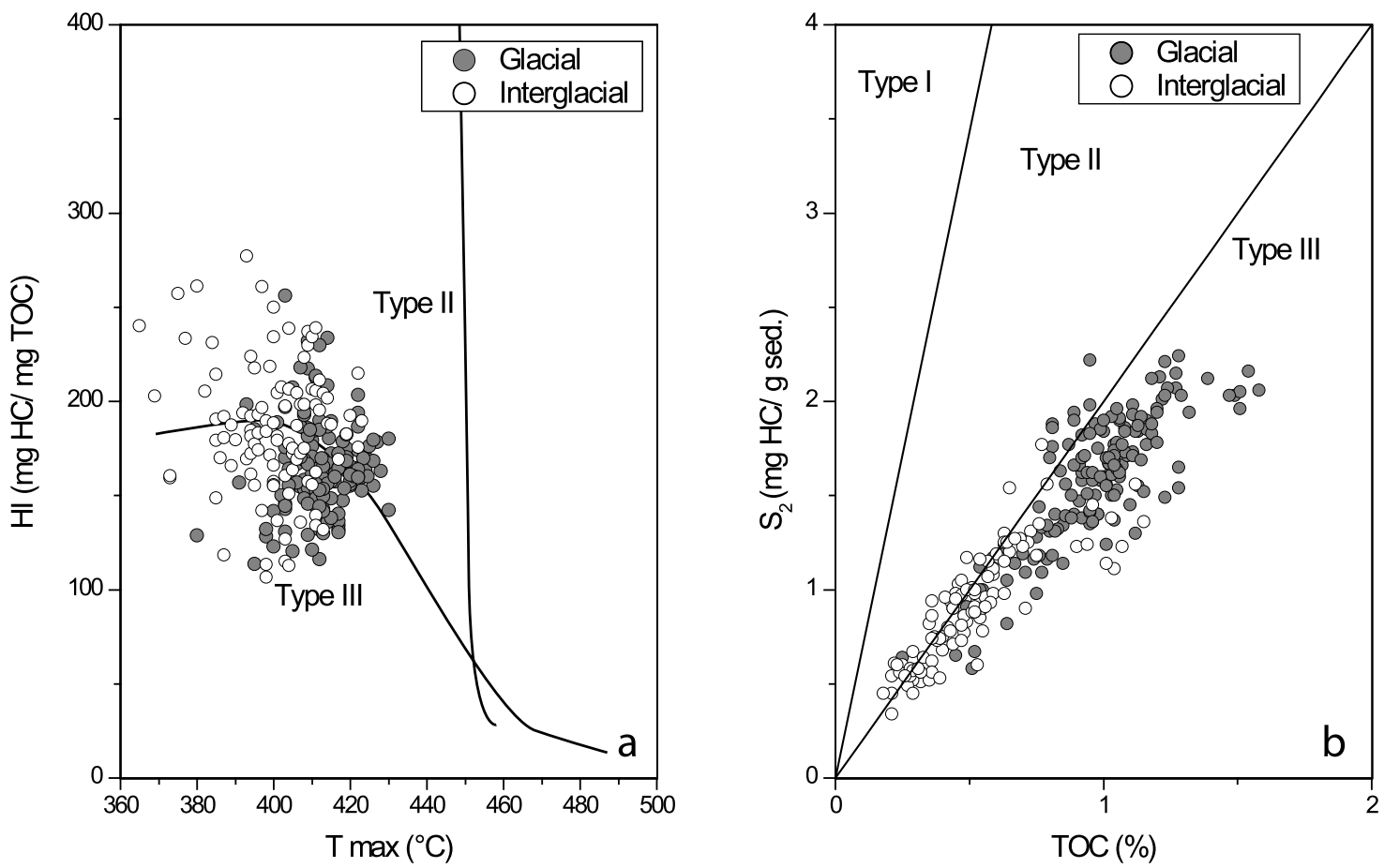

Figure 4. (a) Hydrogen index (HI) versus $T_{\max }\left({ }^{\circ} \mathrm{C}\right)$ and (b) $\mathrm{S}_{2}$ versus TOC diagrams of the glacial and interglacial sediments from MD98-2166. Organic matter is immature and mainly related to type III (terrestrial origin). The boundary between types II/III and types I/II have been settled at values of $\mathrm{HI}=$ 200 and $\mathrm{HI}=700$, respectively [Langford and Blanc-Valleron, 1990].

indicates a size sorting, which is typical for an environment situated far from the source of terrigenous input. By contrast, higher percentages of marine palynomorphs (dinocysts and scolecodonts) are observed in the interglacial samples.

\subsection{Magnetic Susceptibility}

[31] Magnetic susceptibility values from core MD982166 (Figure 3 ) are extremely low $\left(<30 \times 10^{-5} \mathrm{SI}\right)$. MS and $\delta^{18} \mathrm{O}$ values are anticorrelated with higher MS values during interglacial periods. Glacial/interglacial MS fluctuations can be driven by different factors: changes in magnetic source, changes in the input or the preservation of magnetic particles or dilution by carbonates. Among these different factors, several observations suggest that the glacial/interglacial fluctuations in MS record are related to dissolution of magnetic minerals during glacial periods.

[32] 1. The MS and TOC records are inversely correlated with lower MS values during glacial periods when the organic carbon content increases.

[33] 2. There is a general decrease in the interglacial MS values with depth and time. Stage 1 has much higher MS values than those of the rest of the core, including the older interglacial periods. This general long-term decrease is also observed (although to a lesser extent) in the TOC content. Similar depth distribution profiles of organic carbon have been observed in core MD01-2379 in the Timor Sea, which has been attributed to long-term degradation of the organic matter in deeply buried sediments [Gupta and Kawahata, 2006].
[34] 3. The palynofacies studies have indicated high pyrite content during both glacial and interglacial periods. The presence of pyrite is indicative of iron oxide sulphate reduction and leads to the replacement of magnetite by pyrite [Passier and Dekkers, 2002] with much lower MS values.

[35] In addition to glacial/interglacial fluctuations, core MD98-2166 displays several, sharp susceptibility peaks (the two most pronounced being at $73 \mathrm{ka}(11 \mathrm{~m})$ and $193 \mathrm{ka}$ $(20 \mathrm{~m}))$. The Timor Sea is located in an area of important volcanic activity. However, the only ash layers visible during smear slide analyses are located at 27 and $34 \mathrm{~m}$ (out of our age scale) These MS peaks could also correspond to paleoredox fronts that induced the precipitation of magnetic minerals [Reitz et al., 2004]. In support to this interpretation, one can note that these major MS peaks are located at interglacial/glacial transitions at times where sediment also shows low TOC content. Thus it is possible that those MS peaks reflect either increased bottom water oxygenation and/or reduced TOC input. Further analyses will be necessary to test these possibilities.

\subsection{Spectral and Cross-Spectral Analysis}

[36] Spectral analyses of core MD98-2166 reveal peaks at frequencies close to those of orbital eccentricity and obliquity (Figure 6). The frequency likely associated to eccentricity varies between 86 and $129 \mathrm{ka}^{-1}$ in the different records. Because only two climatic cycles are under scrutiny, one cannot expect to get a very accurate estimate of the eccentricity-related oscillations in our record. There is less variability between the proxies for obliquity-related oscil- 


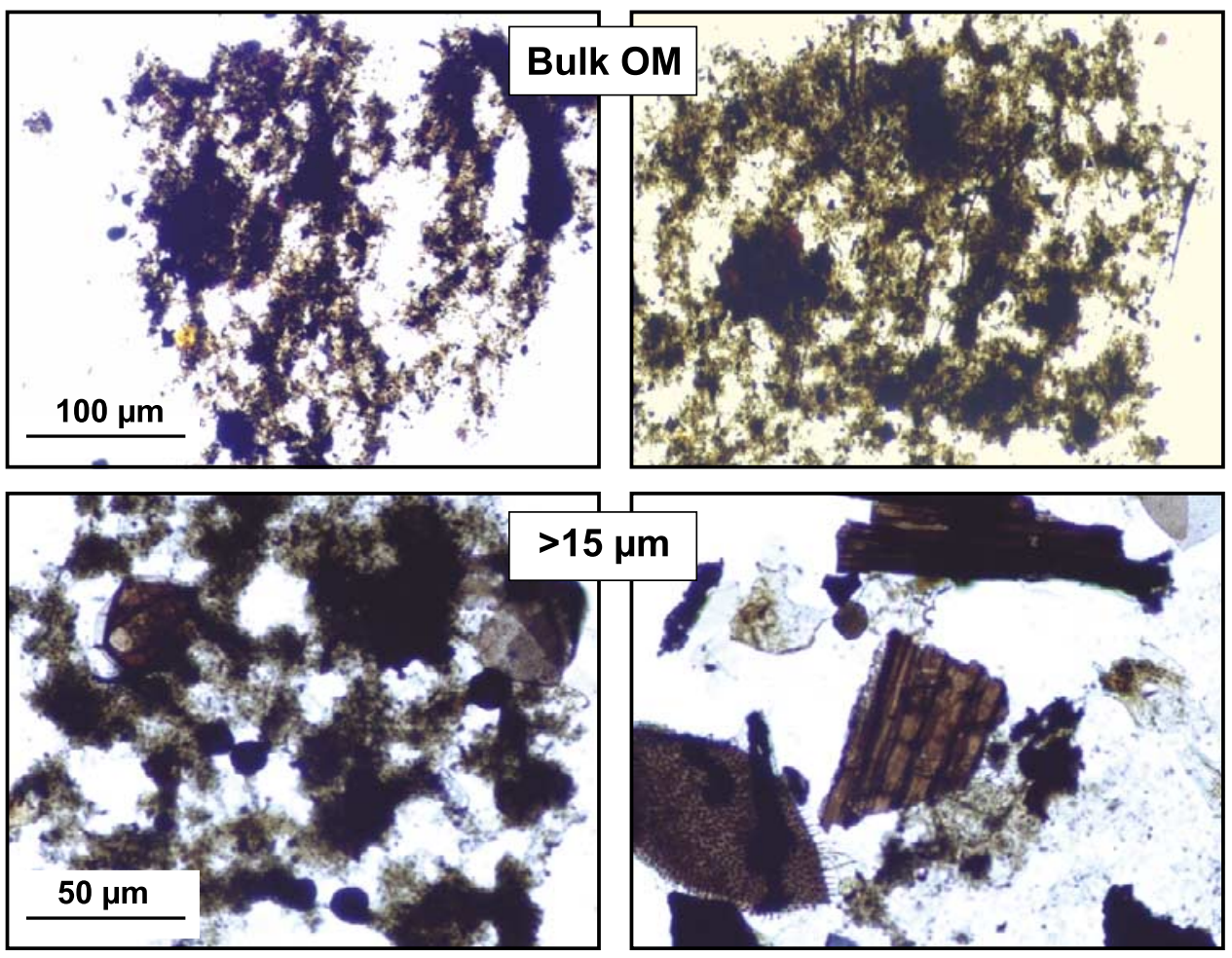

Figure 5. Microphotographs of palynofacies (both bulk and $>15 \mu \mathrm{m}$ sieved) from a typical interglacial sample compared to a glacial sample. The interglacial organic matter is darker, enriched in framboidal pyrite, whereas glacial organic matter is rich in large-sized and well-preserved higher plant debris. Note also the presence of black charcoal debris. OM is organic matter.

lations, which are found between 36 and $39 \mathrm{ka}^{-1}$. The occurrence of eccentricity- and obliquity-related oscillations suggests a response of the proxies to glacial/interglacial variations. The precession period $(23 \mathrm{ka})$ is almost as powerful as the obliquity oscillation in the $\delta^{18} \mathrm{O}$ record, but it is only weakly expressed in the TOC record and is absent in the $\mathrm{CaCO}_{3}$ record. These results contrast with those obtained in nearby core MD01-2378, where dominant frequencies are centered on the $100 \mathrm{ka}^{-1}$ and 23 and $19 \mathrm{ka}^{-1}$ bands [Holbourn et al., 2005].

[37] Table 1 and Figure 7 present the results of crossspectral analyses between $\mathrm{MS}, \mathrm{CaCO}_{3}$ and TOC percentages with the oxygen isotopic record. In order to remain coherent with the conventional "upside down" representation of $\delta^{18} \mathrm{O}$ variations (which has been adopted by paleoceanographers because oxygen isotope changes are inversely related to temperature variations), the inverse oxygen isotopic record $\left(-\delta^{18} \mathrm{O}\right)$ was used in the crossspectral analysis calculations. In Table 1, coherence defines the extent to which two climatic signals are linearly correlated over a given frequency, while the phase shift indicates the lead/lag relationship. Positive (negative) values indicate that $\left(-\delta^{18} \mathrm{O}\right)$ leads (lags) over the other parameter.

[38] Our results show that the strongest coherences between the $\delta^{18} \mathrm{O}$ and the other parameters are obtained at the obliquity and eccentricity bands. An exception is observed for $\mathrm{MS}$ whose maximum coherence with the $\delta^{18} \mathrm{O}$ record corresponds to the precession band. However, the power of MS is very low at this frequency band, suggesting that it is not very significant.

[39] The phase wheels in Figure 7 show that the phase differences between the (inversed) $\delta^{18} \mathrm{O}$ record, on one hand, and TOC content and MS values on the other hand, are very homogeneous for the whole spectrum. The MS and $\left(-\delta^{18} \mathrm{O}\right)$ records show a nearly in-phase relationship at all orbital frequencies (within the limit of uncertainties), whereas the phase shifts between the $\left(-\delta^{18} \mathrm{O}\right)$ and the TOC content correspond to about a half cycle.

[40] Regarding the phase relationship between $\mathrm{CaCO}_{3}$ and $\delta^{18} \mathrm{O}$, there is an important difference between precession and obliquity. In the obliquity band, fluctuations in $\mathrm{CaCO}_{3}$ content lead the (inversed) $\delta^{18} \mathrm{O}$ record by $11 \pm 2 \mathrm{ka}$ (in other words, positive $\mathrm{CaCO}_{3}$ peaks lead the shifts toward more negative values in the $\delta^{18} \mathrm{O}$ record). In the precession band, however, fluctuations in the $\mathrm{CaCO}_{3}$ record lag the (inversed) $\delta^{18} \mathrm{O}$ record by $8 \pm 2 \mathrm{ka}$ (in other words, $\mathrm{CaCO}_{3}$ peaks lead positive shifts in the $\delta^{18} \mathrm{O}$ record by $\sim 3 \pm 2 \mathrm{ka}$ ).

\section{Discussion}

\subsection{Orbital Imprints Within Timor Sea Sedimentary Deposits}

[41] In cores MD98-2166 (this study) and MD01-2378 [Holbourn et al., 2005; Kawamura et al., 2006], spectral 


\section{MD98-2166}
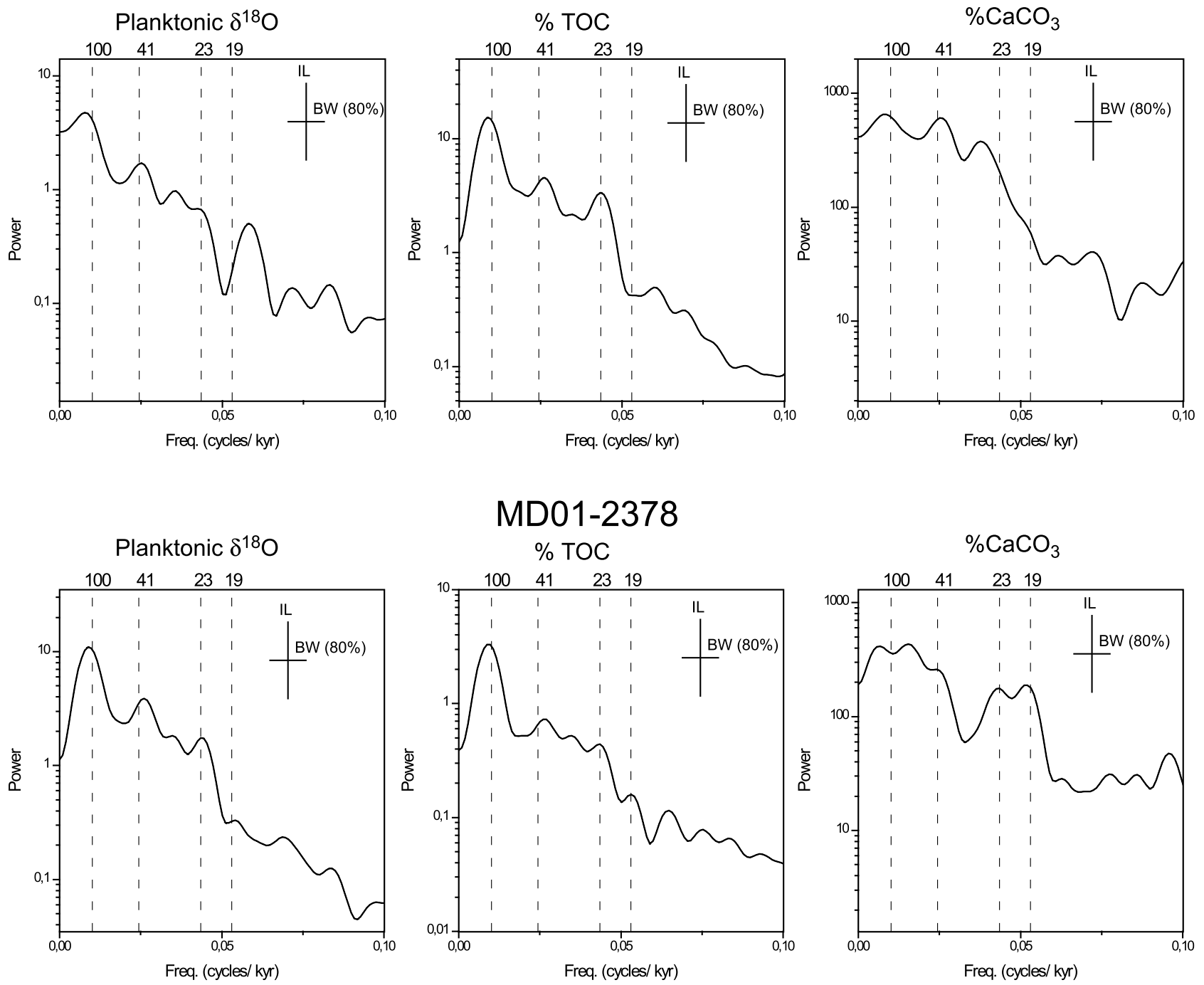

Figure 6. Blackman-Tuckey spectral analysis with 50\% lag of the autocovariance series performed in cores MD98-2166 and MD01-2378 [Holbourn et al., 2005] for the $\delta^{18} \mathrm{O}$, TOC, and $\mathrm{CaCO}_{3}$ records for the last $260 \mathrm{ka}$. The horizontal and vertical bars represent the bandwidth (BW) equal to 0.01158 and the incertitude levels (IL).

analysis demonstrated the influence of orbital forcing on sedimentary changes recorded within the Timor Sea. However, there are important differences in the relative contribution of orbitally related frequencies between these two sedimentary records, which suggest differences in sedimen- tary mechanisms. The $100 \mathrm{ka}^{-1}$ and $41 \mathrm{ka}^{-1}$ frequencies dominate all records in core MD98-2166, whereas in core MD01-2378, the dominant bands are centered at 100, 23 and 19 ka periods [Holbourn et al., 2005].

Table 1. Cross-Spectral Coherencies and Phase Relationships of $\mathrm{CaCO}_{3}$, TOC, $\delta^{13} \mathrm{C}$, and MS With the Planktonic Oxygen Record of Core MD98-2166 ${ }^{\mathrm{a}}$

\begin{tabular}{lllllllc}
\hline & \multicolumn{3}{c}{$41 \mathrm{ka}$} & & \multicolumn{3}{c}{$23 \mathrm{ka}$} \\
\cline { 2 - 3 } & Coherence & Phase, deg & Phase, ka & & Coherence & Phase, deg & Phase, ka \\
\hline $\mathrm{CaCO}_{3}$ & 0.83 & $-102 \pm 17$ & $-11 \pm 2$ & & 0.67 & $131 \pm 29$ & $8 \pm 2$ \\
$\mathrm{TOC}$ & 0.93 & $169 \pm 10$ & $18 \pm 1$ & & 0.89 & $160 \pm 13$ & $10 \pm 1$ \\
$\mathrm{MS}$ & 0.73 & $1 \pm 25$ & $0 \pm 3$ & & 0.81 & $-19 \pm 19$ & $-1 \pm 1$ \\
\hline
\end{tabular}

${ }^{a}$ Test statistic for nonzero coherency at $80 \%$ level equals 0.52 . Taking into account that the $\delta^{18} \mathrm{O}$ record has a negative relationship with sea surface temperature and salinity, the record was inversed by multiplication with -1 prior to analysis. 
$41 \mathrm{kyrs}$

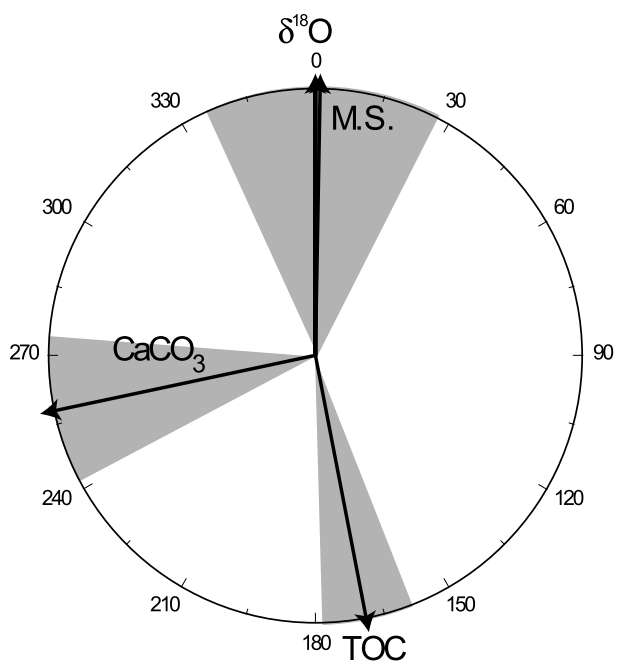

23 kyrs

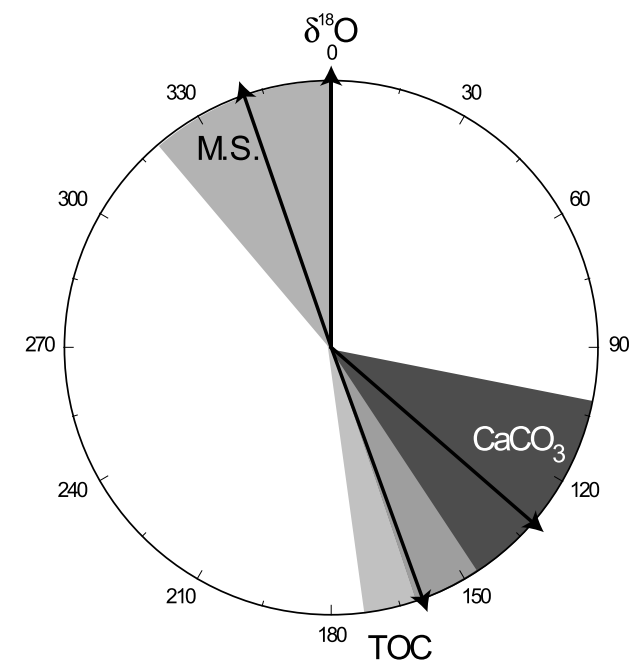

Figure 7. Phase wheels for precession and obliquity that display the phase relationships between the studied proxies and (inversed) $\delta^{18} \mathrm{O}$. Positive sign (counterclockwise) represents a lead and negative sign (clockwise) represents a lag of the $\delta^{18} \mathrm{O}$ over the compared parameter (Table 1).

[42] The precession band is characteristic of low-latitude insolation forcing and, in the Indonesian area, is usually attributed to intertropical variations such as changes in monsoon activity that control rainfall, winds and surface productivity [Holbourn et al., 2005]. Obliquity changes are a major control on insolation at high latitudes and have little effects at lower latitudes. Both obliquity and eccentricityrelated oscillations have been linked to changes in ice volume at high latitudes controlling ice-proximal signals such as sea level changes or oceanic thermohaline circulation [Imbrie et al., 1992, 1993; Ruddiman, 2003]. Thus, even though cores MD98-2166 and MD01-2378 are very close geographically, our results suggest that while sedimentary records in core MD01-2378 do show a clear tropical response, sedimentary records in the deeper core MD98-2166 reflect a stronger influence of processes controlled at high latitude, such as variations in global ice volume (possibly through sea level changes) and/or changes in deep ocean circulation and chemistry.

\subsection{Changes in TOC: Influence of Sea Level and Continental Terrigenous Output}

[43] We have pointed out the strong $41 \mathrm{ka}$ and $100 \mathrm{ka}$ imprint in organic carbon with a higher content and higher abundance of organic plant debris during glacial periods. Moreover, we have indicated that the TOC content most probably controls the selective dissolution of magnetic minerals, with increased dissolution during glacial periods when the TOC content was higher.

[44] In core MD01-2178, Holbourn et al. [2005] interpreted the variations in TOC content and other paleoproductivity records at the precession frequency as reflecting changes in surface productivity controlled by low-latitude insolation forcing of monsoonal wind patterns. These authors interpreted the oscillations with a $\sim 100 \mathrm{ka}$ period as reflecting changes in productivity associated to variations in ITF flow modulated by sea level fluctuations. Models and sedimentary records both indicate that during periods of low sea level, the ITF was maintained but the circulation was reorganized because of the decrease in the size and number of pathways in comparison to today. The present seaway interconnections appeared when the sea level rose to $-30 \mathrm{~m}$ at approximately $11 \mathrm{ka}$ B.P. [De Deckker et al., 2003]. The structure of the upper thermocline was also strongly modified, and could have resulted in planktonic productivity changes [Xu et al., 2006].

[45] However, our data indicate that productivity might not be the only explanation for changes in TOC in core MD98-2166. As indicated earlier, organic carbon in core MD98-2166 has a strong terrestrial signature, especially during glacial periods. The Timor Sea is a marginal sea surrounded by large continental shelves. At the Last Glacial Maximum (LGM), the sea level was about $125 \mathrm{~m}$ lower than today [Yokoyama et al., 2000] and the exposed land almost doubled in this area [De Deckker et al., 2003]. In addition, high-resolution pollen records indicate that climatic conditions were drier during glacial periods [Wang, 1999; van der Kaars et al., 2000]. The prominence of obliquity has been observed in marine palynological records from the northern Australian region, where it indicates the influence of ice volume, through sea level variation, on mangroves vegetation and precipitation [Kershaw et al., 2003].

[46] We suggest therefore that the erosion of exposed, organic rich sediments from the continental shelf during low sea level stands (possibly coeval with increased aridity), and the fact that the MD98-2166 site was nearer to river mouths, are two important mechanisms by which sea level variations may have induced an increased supply of terrestrial organic carbon to the Timor Sea during glacial periods. Our hypothesis is supported by the palynofacies observations, which show an increased abundance of particulate organic 
matter of terrestrial origin (especially land plant debris) during glacial periods

\subsection{CaCO3 Content: Production Versus Preservation at the Seafloor}

[47] We have pointed out the prominence of the obliquityrelated signal in data from core MD98-2166, a signal that is commonly associated with high-latitude ice sheet dynamics and ocean circulation. This obliquity signal is particularly noticeable in the carbonate record (Figure 6) and contrasts with the carbonate record from core MD01-2378, which is dominated by precession. The carbonate content of deep-sea sediments depends on (1) pelagic carbonate productivity, (2) dilution by noncarbonate material and (3) dissolution, which depends upon the corrosiveness of bottom waters $\left(\mathrm{CO}_{2}\right.$ rich) or the in situ oxidation of organic matter during early diagenesis, which increases the $p_{\mathrm{CO} 2}$ in pore water [Martinez et al., 1999]. Pelagic carbonate productivity should not be very different between cores MD98-2166 and MD01-2378 as the two sites are very close geographically. Moreover, the cross spectral analysis between $\delta^{18} \mathrm{O}$ and $\mathrm{CaCO}_{3}$ of core MD98-2166 indicates that $\mathrm{CaCO}_{3}$ leads over $\delta^{18} \mathrm{O}$ in the obliquity band, which suggests that, at this frequency, the carbonate content is independent of changes in local surface hydrology. Thus it is likely that the difference between the $\mathrm{CaCO}_{3}$ records at sites MD982166 and MD01-2378 is due to dissolution.

[48] Core MD98-2166 (3875 $\mathrm{m})$ has been retrieved at a much deeper water depth than core MD01-2378 (1783 m) and the effects of dissolution are therefore stronger in core MD98-2166. Nowadays, in the Indonesian Archipelago the foraminiferal lysocline lies at maximal depths of 2400 $2800 \mathrm{~m}$ north of $15^{\circ} \mathrm{S}$ [Martinez et al., 1998; Ding et al., 2006] but its position altered during glacial-interglacial changes.

[49] The precessional signal in the shallower core MD012378 may reflect the local pelagic carbonate productivity changes [Holbourn et al., 2005]. Because obliquity affects high-latitude insolation with only weak contribution at low latitudes, the dominance of the obliquity signal in core MD98-2166 could reflect changes in the corrosiveness of deep seawater masses in relation to reorganization of deepsea circulation and chemistry at high latitudes.

[50] To test the hypothesis of changes in the corrosiveness of deep waters, carbonate dissolution was estimated in core MD98-2166 by looking at the foraminifera fragmentation index (FI) or the proportion of foraminifera fragments relative to the sum of fragments plus whole foraminifera shells [Thunell, 1976; Bassinot et al., 1994; Le and Shackleton, 1992].

[51] The comparison between the FI and the $\mathrm{CaCO}_{3}$ (Figure 8) indicates that the highest FI values are observed during the Holocene and stage 5e (characterized by low $\mathrm{CaCO}_{3} \%$ ), whereas $\mathrm{FI}$ is much lower during the LGM (characterized by high $\mathrm{CaCO}_{3}$ percentage) and stage 4 . Low fragmentation values are observed at the transitions $2 / 1$ and, especially $5 / 6$ (lowest fragmentation value of the whole record) and could correspond therefore to the wellknown "deglaciation preservation spikes" [Berger, 1977; Peterson and Prell, 1985]. Nevertheless, despite a general anticorrelation between $\mathrm{CaCO}_{3} \%$ and $\mathrm{FI}$, the two records are not mirror images of each other, which clearly indicates that although dissolution plays an important role on $\mathrm{CaCO}_{3} \%$ in core MD98-2166, productivity and dilution also affect it to some degree.

[52] The FI records presents an inverse relationship with the TOC, with lower FI and higher TOC values during glacial periods suggesting that local rains of organic matter does not affect carbonate preservation. Comparison between the FI record in core MD98-2166 (Figure 8) and the reconstructed variations of deep water production (North Atlantic Deep Water) in the Northern Atlantic [Raymo et al., 1990] shows the corrosiveness of the water masses that bathed the site of core MD98-2166 was generally higher (high FI values) during interglacial periods characterized by increased NADW production, whereas glacial periods tend to be associated with less corrosive deep waters. Thus it is apparent that the FI record from core MD98-2166 does track some of the major changes in NADW production and that the strong obliquity signal in the carbonate content is related to a deep-sea circulation reorganization in the Timor Sea, remotely associated with high-latitude changes in deep-sea production.

[53] Today, the site of core MD98-2166, at $3875 \mathrm{~m}$, is located at the transition between the North Indian Deep Water (NIDW), which extends from $2000 \mathrm{~m}$ to $3800-4000 \mathrm{~m}$ of water depth, and the Lower Circumpolar Deep Water (LCDW), which is located below [Murgese and De Deckker, 2005]. Geochemical data obtained at the nearest GEOSECS site 438 show that the NIDW has a higher total $\mathrm{CO}_{2}$ content $\left(2310 \mu \mathrm{mol} \mathrm{L}^{-1}\right.$ on average) than the better ventilated LCDW (average total $\mathrm{CO}_{2}=2295 \mu \mathrm{mol} \mathrm{L}^{-1}$ ) [Weiss et al., 1983]. Recently published, benthic $\delta^{13} \mathrm{C}$ record from Timor Sea core SHI-9006 [Murgese and De Deckker, 2007], located at about $2400 \mathrm{~m}$ of water depth, shows that the LGM corresponds to a period of reduced NIDW ventilation and activity.

[54] We propose therefore that during glacial periods, the decrease in NIDW activity, in conjunction with the reduced production of NADW at high latitudes, was coeval with an upward extension of the better ventilated underlying LCDW water mass, which contains less dissolved $\mathrm{CO}_{2}$ and could explain therefore the better preservation of $\mathrm{CaCO}_{3}$ in core MD98-2166.

\section{Conclusion}

[55] The study of core MD98-2166 (3875 m of water depth in the Timor Sea) pointed out important glacial/ interglacial changes in the sedimentary records, especially in the $\mathrm{CaCO}_{3}$ and TOC records. The comparison with a previous study performed on nearby core MD01-2378, collected at a shallower depth (1783 m [Holbourn et al., 2005]), revealed significant differences in the relative contribution of orbitally related frequencies imprinted in these two sedimentary records. The $100 \mathrm{ka}$ and $41 \mathrm{ka}$ frequencies dominate all records from core MD98-2166, whereas in core MD01-2378, the dominant bands are centered at the $100 \mathrm{ka}, 23 \mathrm{ka}$ and $19 \mathrm{ka}$ periods.

[56] We suggest that while the $\mathrm{CaCO}_{3}$ record in core MD01-2378 does show a clear low-latitude response related with surface productivity, the strong imprint of obliquity in the MD98-2166 record reflects carbonate dissolution under 


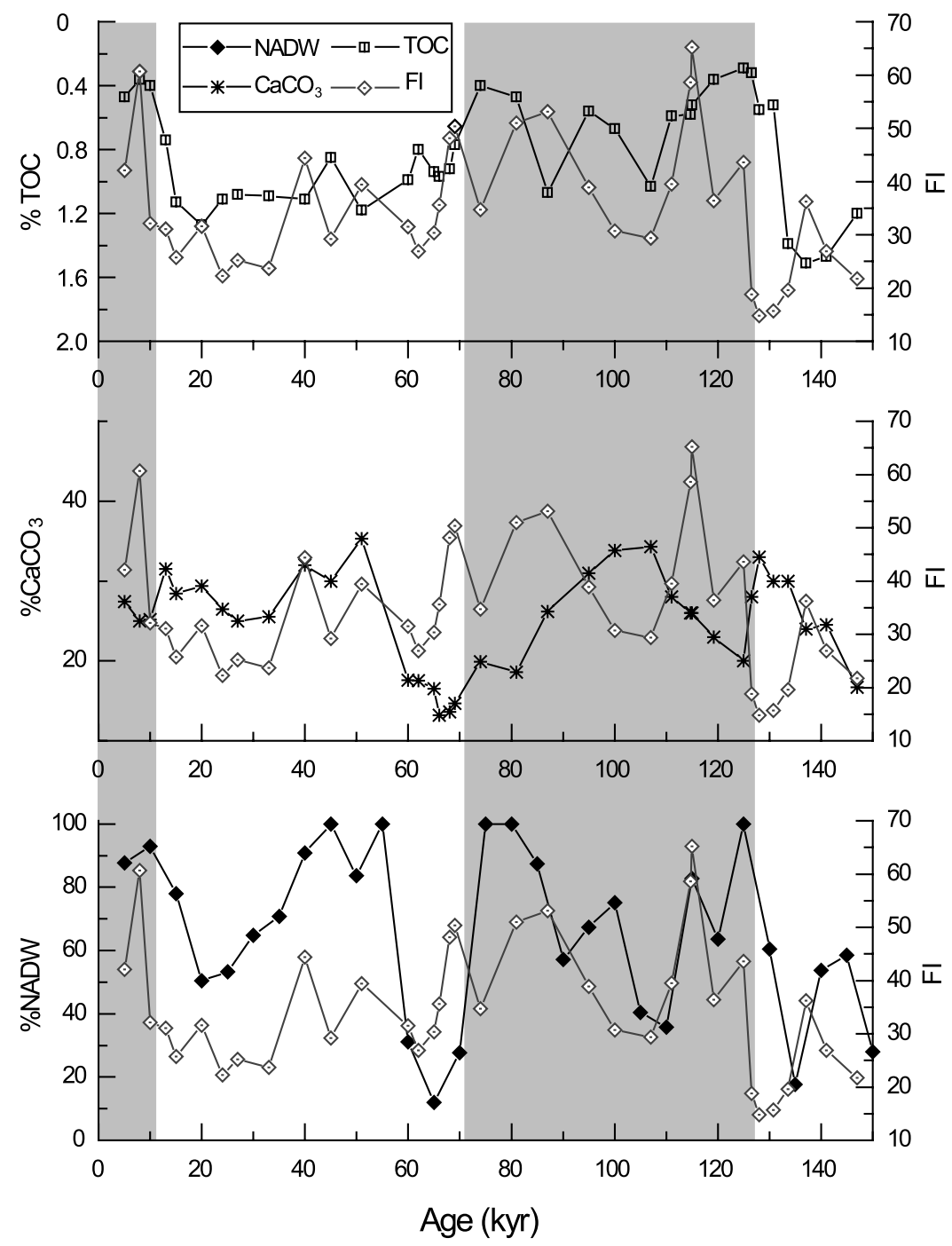

Figure 8. Comparison between the fragmentation index (FI), TOC, and the $\mathrm{CaCO}_{3}$ content in core MD98-2166 with NADW fluctuations estimated by Raymo et al. [1990].

the control of deep water circulation changes and the upward displacement of the limit between the $\mathrm{CO}_{2}$ richer NIDW and the $\mathrm{CO}_{2}$ poorer LCDW. The TOC and RockEval results from core MD98-2166 indicate a non negligible contribution of terrestrial organic matter. This suggests that besides the pelagic productivity influence, the increase in TOC content during glacial periods might be due at least in part to an increased transfer of terrestrial organic matter to the deep sea during periods of low sea level.
[57] Acknowledgments. We are extremely grateful to the officer, crew, and scientists on board R/V "Marion Dufresne" for their help during the MD111-IMAGES IV cruise. We acknowledge the financial support of the French programme of the MNHN Plan Pluriformation "Structure et Evolution des Ecosystèmes." We acknowledge the technical and sample preparation support of Pierre Jean Giannesini and Anne Marie Brunet. We thank Ann Holbourn and Min-Te Chen for their constructive and useful reviews, which greatly improved our manuscript. Sample material used in this project was provided by the MNHN Deep-Sea Sample Repository. This is LSCE contribution 2811.

\section{References}

Bassinot, F. C., L. Beaufort, E. Vincent, L. D. Labeyrie, F. Rostek, P. J. Müller, X. Quidelleur, and Y. Lancelot (1994), Coarse fraction fluctuations in pelagic carbonate sediments from the tropical Indian Ocean: A 1500-kyr record of carbonate dissolution, Paleoceanography, 9, 579-600.

Berger, W. H. (1977), Deep-sea carbonate and the deglaciation preservation spike in pteropods and foraminifera, Nature, 269, 301-304.
Bloemendal, J., J. W. King, F. R. Hall, and S. J. Doh (1992), Rock magnetism of late Neogene and Pleistocene deep-sea sediments: Relation to sediment source, diagenetic processes and sediment lithology, J. Geophys. Res., 97, $4361-4375$.

Cane, M., and A. Clement (1999), A role for the tropical Pacific coupled ocean-atmosphere system on Milankovitch and millennial timescales, part II: Global impacts, in Mechanisms of Glo- bal Climate Change at Millennial Scales, edited by P. U. Clark, R. S. Webb, and L. D. Keigwin, Geophys. Monogr. Ser., vol. 112, pp. 373-393, Washington, D. C.

Coplen, T. B. (1988), Normalization of oxygen and hydrogen isotope data, Chem. Geol., 72, 293-297.

De Deckker, P., N. J. Tapper, and S. van der Kaars (2003), The status of the Indo-Pacific Warm Pool and adjacent land at the Last Gla- 
cial Maximum, Global Planet. Change, 35, $25-35$.

Demory, F., H. Oberhansli, N. R. Nowaczyk, M. Gottschalk, R. Wirth, and R. Naumann (2005), Detrital input and early diagenesis in sediments from Lake Baikal revealed by rock magnetism, Global Planet. Sci., 46, 145-166.

Ding, X., F. Bassinot, F. Guichard, Q. Y. Li, N. Q. Fang, L. Labeyrie, R. C. Xin, M. K. Adisaputra, and K. Hardjawidjaksana (2006), Distribution and ecology of planktonic foraminifera from the seas around the Indonesian Archipelago, Mar. Micropaleontol., 58, 114-134.

Espitalié, J., G. Deroo, and F. Marquis (1985), La pyrolyse Rock Eval et ses applications (deuxième partie), Rev. Inst. Fr. Pet., 40, $755-784$.

Ganachaud, A., and C. Wunsch (2000), Improved estimates of global ocean circulation, heat transport and mixing from hydrographic data, Nature, 408, 453-457.

Gingele, F., P. De Deckker, A. Girault, and F. Guichard (2002), History of the South Java Current over the past $80 \mathrm{ka}$, Palaeogeogr. Palaeoclimatol. Palaeoecol., 183, 247-260.

Gupta, L. P., and H. Kawahata (2006), Downcore diagenetic changes in organic matter and implications for paleoproductivity estimates, Global Planet. Change, 53, 122-136.

Holbourn, A., W. Kuhnt, H. Kawamura, Z. Jian, P. Grootes, H. Erlenkeuser, and J. Xu (2005), Orbitally paced paleoproductivity variations in the Timor Sea and Indonesian Throughflow variability during the last $460 \mathrm{kyr}$, Paleoceanography, 20, PA3002, doi:10.1029/ 2004PA001094

Imbrie, J., et al. (1992), On the structure and origin of major glaciation cycles: 1 . Linear responses to Milankovitch forcing, Paleoceanography, 7, 701-738.

Imbrie, J., et al. (1993), On the structure and origin of major glaciation cycles: 2 . The 100,000-year cycle, Paleoceanography, 8, $699-735$

Kawamura, H., A. Holbourn, and W. Kuhnt (2006), Climate variability and land-ocean interactions in the Indo Pacific Warm Pool: A 460-ka palynological and organic geochemical record from the Timor Sea, Mar. Micropaleontol., 59, 1-14.

Kershaw, A. P., S. van der Kaars, and P. T. Moss (2003), Late Quaternary Milankovitch-scale climatic change and variability and its impact on monsoonal Australasia, Mar. Geol., 201, $81-95$.

Langford, F. F., and M. M. Blanc-Valleron (1990), Interpreting Rock-Eval pyrolysis data using graphs of pyrolizable hydrocarbons vs. total organic carbon, AAPG Bull., 74, 799-804.

Larrasoana, J. C., A. P. Roberts, J. S. Stoner, C. Richter, and R. Wehausen (2003), A new proxy for bottom-water ventilation in the eastern Mediterranean based on diagenetically controlled magnetic properties of sapropelbearing sediments, Palaeogeogr. Palaeoclimatol. Palaeoecol., 190, 221-242.

Le, J., and N. J. Shackleton (1992), Carbonate dissolution fluctuations in the western equatorial Pacific during the late Quaternary, Paleoceanography, 7, 21-42.

Levi, C. (2003), Étude des variations climatiques de la zone Indo-Pacifique: Rôle des basses latitudes dans la variabilité millénaire du climat, Ph.D thesis, Univ. of Paris 11, Orsay, France.

Macdonald, A. M. (1998), The global ocean circulation: A hydrographic estimate and regional analysis, Prog. Oceanogr., 41, 281-382.
Martinez, J. I., L. Taylor, P. De Deckker, and T. Barrows (1998), Planktonic foraminifera from the eastern Indian Ocean: Distribution and ecology in relation to the Western Pacific Warm Pool (WPWP), Mar. Micropaleontol., $34,121-151$.

Martinez, J. I., P. De Deckker, and T. T. Barrows (1999), Palaeoceanography of the Last Glacial Maximum in the eastern Indian Ocean: Planktonic foraminiferal evidence, Palaeogeogr. $\mathrm{Pa}$ laeoclimatol. Palaeoecol., 147, 73-99.

Moreno, E., N. Thouveny, D. Delanghe, I. N McCave, and N. J. Shackleton (2002), Climatic and oceanographic changes in the Northeast Atlantic reflected by magnetic propertie of sediments deposited on the Portuguese margin during the last $340 \mathrm{ka}$, Earth Planet. Sci. Lett., 202, 465-480.

Müller, A., and B. N. Opdyke (2000), Glacialinterglacial changes in nutrient utilization and paleoproductivity in the Indonesian Throughflow sensitive Timor Trough, easternmost Indian Ocean, Paleoceanography, 15, 85-94.

Murgese, D. S., and P. De Deckker (2005), The distribution of deep-sea benthic foraminifera in core tops from the eastern Indian Ocean, Mar. Micropaleontol., 56, 25-49.

Murgese, D. S., and P. De Deckker (2007), The Late Quaternary evolution of water masses in the eastern Indian Ocean between Australia and Indonesia, based on benthic foraminifera faunal and carbon isotopes analyses, Palaeogeogr. Palaeoclimatol. Palaoecol., 247, $382-$ 401 .

Paillard, D., L. Labeyrie, and P. Yiou (1996), Macintosh program performs time-series analysis, Eos Trans. AGU, 77(39), 379.

Passier, H. F., and M. J. Dekkers (2002), Iron oxide formation in the active oxidation fron above sapropel S1 in the eastern Mediterranean Sea as derived from low-temperature magnetism, Geophys. J., 150, 230-240.

Passier, H. F., M. J. Dekkers, and G. J. D. Lange (1998), Sediment chemistry and magnetic properties in an anomalously reducing core from eastern Mediterranean Sea, Chem. Geol. $152,287-306$

Peters, C., and M. J. Dekkers (2003), Selected room temperature magnetic parameters as a function of mineralogy, concentration and grain size, Phys. Chem. Earth, Parts $A / B / C$ $28,659-667$.

Peters, K. E. (1986), Guidelines for evaluating petroleum source rock using programmed pyrolysis, AAPG Bull., 70, 318-329.

Peterson, L. C., and W. L. Prell (1985), Carbonate preservation and rates of climate change: An $800 \mathrm{kyr}$ record from the Indian Ocean, in The Carbon Cycle and Atmospheric $\mathrm{CO}_{2}$ Natural Variations, Archean to Present, Geophys. Monogr. Ser., vol. 32, edited by E. T. Sundquist and W. S. Broecker, pp. 251-270, AGU, Washington, D. C.

Ramage, C. S. (1968), Role of a tropical maritime continent in the atmospheric circulation, Mon. Weather Rev., 96, 365-370.

Raymo, M. E., W. F. Ruddiman, N. J. Shackleton, and D. Oppo (1990), Evolution of AtlanticPacific $\delta^{13} \mathrm{C}$ gradients over the last $2.5 \mathrm{My}$, Earth Planet. Change, 97, 353-368.

Reitz, A., C. Hensen, S. Kasten, J. A. Funk, and G. J. de Lange (2004), A combined geochemical and rock-magnetic investigation of a redox horizon at the last glacial/interglacial transition, Paleo Rock Environ. Magn., 29, 921-931.

Roberts, A. P., and G. M. Turner (1993), Diagenetic formation of ferrimagnetic iron sulphide minerals in rapidly deposited marine sedi- ments, South Island, New Zealand, Earth Planet. Sci. Lett., 115, 257-273.

Robinson, S. G. (2001), Early diagenesis in an organic-rich turbidite and pelagic clay sequence from the Cape Verde abyssal plain NE Atlantic: Magnetic and geochemical signals, Sediment. Geol., 143, 91-123.

Ruddiman, W. F. (2003), Orbital insolation, ice volume and greenhouse gases, Quat. Sci. Rev., 22, 1597-1629.

Stott, L., C. Poulsen, S. Lund, and R. Thunell (2002), Super ENSO and global climate oscillations at millennial time scales, Science, 297. $222-226$.

Széréméta, N., F. Bassinot, Y. Balut, L. D. Labeyrie, and M. Pagel (2004), Oversampling of sedimentary series collected by giant piston corer: Evidence and corrections based on $3.5 \mathrm{kHz}$ chirp profiles, Paleoceanography, 19, PA1005, doi:10.1029/2002PA000795.

Thompson, R., and F. Oldfield (1986), Environmental Magnetism, 1st ed., 227 pp., Allen and Unwin, London.

Thomson, J., N. C. Higgs, and S. Colley (1996), Diagenetic redistributions of redox-sensitive elements in northeast Atlantic glacial/interglacial transition sediments, Earth Planet. Sci. Lett., 139, 365-377.

Thouveny, N., E. Moreno, D. Delanghe, L. Candon, Y. Lancelot, and N. J. Shackleton (2000), Rock magnetic detection of distal ice-rafted debries Clue for the identification of Heinrich layers on the Portuguese margin, Earth Planet. Sci. Lett., $180,61-75$.

Thunell, R. C. (1976), Calcium carbonate dissolution history in late Quaternary deep-sea sediments, Western Gulf of Mexico, J. Quaternary Research, 6, 281-297.

Tissot, B. P., and D. H. Welte (1984), Petroleum Formation and Occurrence, 2nd ed., 699 pp., Springer, Berlin.

Tyson, R. V. (1995), Sedimentary Organic Matter: Organic Facies and Palynofacies, 615 pp. Chapman and Hall, London.

van der Kaars, S., X. Wang, P. Kershaw, F. Guichard, and D. Arifin Setiabudi (2000), A late Quaternary palaeoecological record from the Banda Sea, Indonesia: Patterns of vegetation, climate and biomass burning in Indonesia and northern Australia, Palaeogeogr. Palaeoclimatol. Pa laeoecol., 155, 135-153.

Visser, K., R. Thunell, and M. A. Goni (2004), Glacial-interglacial organic carbon record from the Makassar Strait, Indonesia: Implications for regional changes in continental vegetation, Quat. Sci. Rev., 23, 17-27.

Waelbroeck, C., C. Levi, J. C. Duplessy, L. Labeyrie, E. Michel, E. Cortijo, F. Bassinot, and F. Guichard (2006), Distant origin of circulation changes in the Indian Ocean during the last deglaciation, Earth Planet. Change, 243, 244-251.

Wang, P. (1999), Response of western Pacific marginal seas to glacial cycles: Paleoceanographic and sedimentological features, Mar Geol., 156, 5-39.

Wang, X., S. van der Kaars, P. Kershaw, M. Bird, and F. Jansen (1999), A record of fire, vegetation and climate through the last three glacia cycles from Lombok Ridge core G6-4, eastern Indian Ocean, Indonesia, Palaeogeogr. $\mathrm{Pa}$ laeoclimatol. Palaeoecol., 147, 241-256.

Weiss, R. F., W. S. Broecker, H. Craig, and D. Spencer (1983), GEOSECS Indian Ocean Expedition, vol. 5, Hydrographic Data, 1977-1978, Natl. Sci. Found., Washington, D. C.

Xu, J., W. Kuhnt, A. Holbourn, N. Andersen, and G. Bartoli (2006), Changes in the vertical 
profile of the Indonesian Throughflow during Termination II: Evidence from the Timor Sea, Paleoceanography, 21, PA4202, doi:10.1029/ 2006PA001278

Yan, X. H., C. R. Ho, Q. Zheng, and V. Klemas (1992), Temperature and size variability of the Western Pacific Warm Pool, Science, 258, $1643-1645$.

Yokoyama, Y., K. Lambeck, P. De Deckker, P. Johnston, and L. K. Fifield (2000), Timing of the Last Glacial Maximum from observed sea-level minima, Nature, 406, 713-716.

F. Bassinot, Laboratoire des Sciences du Climat et de l'Environnement, Domaine du CNRS, F-91198 Gif-sur-Yvette, France.

F. Baudin, UMR 7072 and Département de Géologie Sédimentaire, Université Pierre et
Marie Curie Paris 6, F-75252 Paris cedex 05, France.

E. Moreno and M.-T. Vénec-Peyré, UMR 5143, Département d'Histoire de la Terre, Muséum National d'Histoire Naturelle (MNHN-CNRS-UPMC), F-75005 Paris, France. (emoreno@mnhn.fr) 